\title{
The impact of market orientation on university spin-off business performance
}

\author{
Nicoletta Buratti ${ }^{1}$ (D) Giorgia Profumo $^{1}$ (D) $\cdot$ Luca Persico $^{1}$
}

Published online: 20 August 2020

(C) The Author(s) 2020

\begin{abstract}
Extant literature on the antecedents of university spin-off (USO) business performance has developed with the aim of highlighting those drivers that could foster the performance of such firms, focusing on a variety of factors. Less interest has been devoted to the market orientation-performance relationship, despite the positive link frequently found in the marketing literature. The aim of the present paper is therefore to fill this gap and investigate the relationship between market orientation (MO) and USO performance using the Netval database of Italian research spin-offs. To measure MO, we adopted an ad hoc questionnaire, and after testing its validity with a factor analysis, we performed a regression model. The results show that MO, particularly some of its components (customer intelligence generation, intelligence dissemination, integration and inter-functional coordination), has an impact on business performance. This contribution presents some valuable research implications useful for academics, but professionals from new high-tech ventures and technology transfer offices may also benefit from this knowledge.
\end{abstract}

Nicoletta Buratti

buratti@economia.unige.it

1 Department of Economics and Business Studies, University of Genoa, Via Francesco Vivaldi 5, 16126 Genoa, Italy 


\section{Résumé}

Une importante bibliographie sur les antécédents de la performance des spin-off universitaires a déjà été développée, dans le but de mettre en évidence les éléments qui pourraient favoriser la performance de ces entreprises, et en mettant l'accent sur divers facteurs. Malgré le lien positif qui est généralement observé dans la littérature marketing, la relation entre l'Orientation Marché $(O M)$ et la performance a été moins approfondie. L'objectif de cet article est donc de combler cette lacune en examinant la relation entre l'orientation marché et les performances des SOU (Spin-Off Universitaires) de la base de données Netval, dédiée aux spin-off de la recherche italienne. Afin de mesurer l'OM, nous avons adopté un questionnaire ad hoc et, après avoir testé sa validité avec une analyse factorielle, nous avons réalisé un modèle de régression. Les résultats montrent que l'OM a effectivement un impact sur la performance de l'entreprise, en particulier sur certaines de ses dimensions (production de renseignements sur les clients, diffusion de renseignements, intégration et coordination interfonctionnelle). Cette étude présente des perspectives de recherche utiles pour les universitaires, mais aussi pour les professionnels des nouvelles entreprises haute technologie et les bureaux de transfert de technologie, qui pourraient bénéficier de ces connaissances.

Keywords University spin-off · Market orientation · Business performance $\cdot$ Academic entrepreneurship · Factor analysis

Mots clés Spin-off universitaire · Orientation Marché · Performance des entreprises · Entrepreneuriat universitaire $\cdot$ Analyse factorielle

JEL classification M13 $\cdot$ M31

\section{Summary highlights}

Contributions: The study offers a better understanding of the span of applicability of Market Orientation (MO) concept. While most of the previous studies examined larger companies, our study focuses on university spin-offs (USOs), offering empirical evidence of the positive relationship between MO and business performance in the context of new ventures stemming from academic departments and research laboratories. Moreover, by testing a scale for measuring the level of MO in USOs, it offers a research tool that might be used in future studies on other countries or comparative analyses.

Research Questions: Which dimensions of MO are relevant for USOs? How do the different dimensions of MO affect USO business performance?

Data: Data were collected through a structured questionnaire, built using both MKTOR and MARKOR scales, submitted on-line, via Google Forms, to the population of the Italian University spin-offs surveyed in the Netval database in 2015. A total of 115 USOs completed the survey. 
Methods: After the validation of the MO scale through a factor analysis (EFA and CFA), the extracted MO factors have been used in an OLS regression to investigate the impact of MO dimensions on business performance.

Results/Findings: The results show that the MO construct in USOs may be split into four dimensions, but not all the dimensions of the MO construct present the same effect on business performance. In particular, responsive customer intelligence generation (RCIG) and dissemination, integration and inter-functional coordination (DIIC) seem to positively affect business performance; proactive customer intelligence generation (PCIG) reveals a negative impact, while competitor intelligence generation (CIGE) presents a non-significant effect on business performance.

Limitations: The study takes into account only one financial year. Further studies would benefit from using longitudinal analyses. Another limitation is related to the measurement of firms' business performance. Sales revenues to number of employees is a good measure, but in the future, new measures of business performance should be used, not necessarily linked to financial results.

Theoretical Implications: The study adds some reflections within the academic entrepreneurship literature, highlighting the relevance of being market oriented in order to attain better results when exploiting research for commercial purpose. Within the market orientation literature, the study confirms the importance of examining MO in a disaggregated manner and improves the knowledge on its application and measurement in the context of new ventures, such as USOs.

Practical Implications: Results may be useful for both entrepreneurial teams of USOs and technology transfer offices, as they highlight the relevance of being market oriented in order to improve the business performance of this kind of firms.

Public Policy Implications and Recommendations: Support programs aimed at fostering the setting up and development of USOs should provide guidance and assistance to these firms in order to facilitate their adoption of market-oriented attitudes and behaviours.

\section{Introduction}

University spin-offs (USOs), which are created with the purpose of commercializing knowledge, technology or research results stemming from a university, are an important subset of start-up firms that are capable of becoming an economically powerful group of high technology companies and therefore attract the attention of policy makers and technology transfer institutions (Shane and Stuart 2002; Heirman and Clarysse 2004; Lerner 2004; O'Shea et al. 2005).

Despite the importance national and local governments attribute to university spinoffs as a driver of local economic development, the analysis of their performance shows high survival rates but slow growth, especially for companies based in the EU, compared with US new technology ventures. 
Moreover, difficulties developing and maintaining a sustainable competitive advantage over time appear to be widespread (Di Gregorio and Shane 2003; Mustar et al. 2008; Yagüe-Perales and March-Chordà 2012; Buratti et al. 2014a, b, 2015).

Based on this evidence, some studies have tried to highlight the possible causes of such performance limitations (among others: O'Shea et al. 2005; Wu 2007; Fitza et al. 2009; Helm et al. 2010; Hesse and Sternberg 2017), pointing out, among their weaknesses, the way such firms are run. Often, new tech ventures, especially USOs, are managed more as research laboratories than as real companies, and in particular, scarce attention is given to potential markets and primary actors (customers and competitors), especially in the first years of activity. As some have emphasized, academics may be skilled at innovating within the research domain; yet, this may be of little use for identifying opportunities within the commercial context (Lockett et al. 2005; Rasmussen et al. 2011).

For these reasons, one could argue that to obtain better results, these new ventures should develop a market-oriented perspective towards doing business from the very first years of their lives, which in turn should have a positive impact on business performance.

It is already widely accepted that market orientation (MO) has a positive influence on firm performance (Narver and Slater 1990; Jaworski and Kohli 1993; Pitt et al. 1996; Chang and Chen 1998; Deshpandé 1999; Matsuno and Mentzer 2000; Raju et al. 2000; De Luca et al. 2010).

Unfortunately, although this relationship has been the focus of many studies, little research to date has concentrated on the context of smaller organizations, even though they are important for many European economies (Appiah-Adu 1998; Pelham 2000; Verhees and Meulenberg 2004; Kara et al. 2005; Keskin 2006; Raju et al. 2011; Polo Peña et al. 2011). Even fewer studies have focused on new tech ventures, such as USOs (Roskos and Klandt 2007; Abbate and Cesaroni 2014, Abbate and Cesaroni 2017; Migliori et al. 2019).

Based on these assumptions, our work aims to address the relationship between MO and business performance using a sample of Italian USOs present in the Netval (Italian Network of Technology Transfer Offices of Universities and Public Research Organizations) database.

We first measured the level of MO through a questionnaire mainly based on scales used in previous studies (Narver and Slater 1990; Narver et al. 2004; Kohli et al. 1993; Mohr et al. 2010; Abbate and Cesaroni 2014). We then tested its validity through an exploratory factor analysis (EFA) followed by a confirmatory factor analysis (CFA), in which the principal dimensions of MO were highlighted. Finally, we controlled the effect of MO on firms' business performance. In particular, as the construct of market orientation has been conceptualized into distinctive components, we inspected the relationship with firms' business performance at the single component level, as has been done in other studies (Han et al. 1998).

The present study contributes to the extant literature on USOs in several ways. First, it offers empirical evidence of the positive relationship between $\mathrm{MO}$ and business performance in the context of new ventures stemming from academic departments and research laboratories. This result is not as trivial as one might expect, so we presume that it might be useful for both university-based entrepreneurs and policy makers looking for best practices.

Second, testing a scale for measuring the level of MO in USOs offers insights into a quite unexplored subject and a research tool that might be used in future studies on other countries or in comparative analyses. 
Finally, one could argue that our study offers a better understanding of the span of applicability of the MO concept. Most of the previous studies examined larger companies (Narver and Slater 1990; Jaworski and Kohli 1993), and only a few have assessed the level of MO in young tech ventures and academic spin-offs (Roskos and Klandt 2007; Abbate and Cesaroni 2014). Since such types of firms usually work in dynamic and uncertain environments that force them to adopt an outward approach to business management, it is worthwhile studying how MO is conceptualized by such new ventures and its relationship with their business performance.

The remainder of the paper is organized as follows. First, prior studies on USOs and on the relationship between market orientation and firms' business performance are reviewed to develop the research questions. Second, the adopted methodology is specified, and the sample is described: university spin-offs in Italy surveyed by Netval. Third, the results of the analysis, together with a formal discussion of practical implications, are developed. Finally, the limitations of the study and suggestions for further research are summarized.

\section{Conceptual framework}

\section{University spin-offs and market orientation}

University spin-offs are business ventures (1) that originate from university research laboratories, (2) whose founder(s) choose to work in the private sector (at least partially) and (3) whose primary asset is a core technology transferred from the parent university.

These firms present some distinctive features stemming from the fact that the founders are most often engineers and scientists and that their orientation in running a business is very often influenced by their original motivations and personal status (Perez and Sánchez 2003; Walter et al. 2006). Sometimes, founders manage their business without much assurance of successful commercialization of the technology, as they may be driven by the desire to prove the new technology (technological obsession), and only a few may actually be motivated by the prospect of meeting market needs.

Moreover, university spin-offs based in European countries (and especially in Italy, due to specific legislation regarding the engagement of academics in start-up ventures) may be established to provide employment opportunities to young researchers and collaborators, while professors maintain their academic position at university (opportunistic motivation). For these reasons, the engagement of academic founders in the new start-up is limited, giving rise to so-called "hybrid entrepreneurship" (Nicolaou and Birley 2003), a form of entrepreneurship characterized by a low degree of risk taking and proactiveness. ${ }^{1}$

\footnotetext{
${ }^{1}$ Entrepreneurial orientation (EO) has been traditionally considered a basic component required to obtain superior performance, especially in dynamic and turbulent environments. The literature offers different perspectives and defines the characterizing dimensions of EO (Miller 1983; Covin and Covin 1990; Lumpkin and Dess 1996); following Miller's approach (1983), we can consider EO to be the expression of three basic features: willingness to take risks, innovativeness (focus on innovation as a source of competitive advantage) and proactivity (propensity to beat competitors and actively seek business opportunities). USOs are very often expression of hybrid entrepreneurship characterized by innovativeness but lacking willingness to take risks and proactive business management.
} 
University spin-offs with a technological "obsession" may be tempted to avoid the process of market learning, while those with an "opportunistic" motivation may tend to overlook the relevance of investing in intelligence generation and dissemination activities, as their business is primarily focused on financed $R \& D$ projects and research contracts. One of the major consequences is a generalized failure to consider the strategic value of the resources and competencies necessary to commercialize technological innovations (Würmseher 2017) or, even worse, a failure to direct attention towards potential customer needs, market attractiveness and competitive threats.

This is quite surprising, as successful USOs require a mix of technological and marketing competencies. They are set up to market R\&D outcomes from university labs, find appropriate applications or even build entire markets ex novo (Migliori et al. 2019); they are therefore forced to implement specific activities based on integrating technical and market knowledge (Walsh et al. 2002; Walsh and Linton 2011).

For these firms, being market oriented might be a key driver for surviving in a hostile environment and a source of competitive advantage over time. Such orientation can also be seen as a corporate capability that may facilitate the development of a company's internationalization strategy, especially in its earlier stages (Armario et al. 2008). This could be particularly important for USOs: companies with such advanced technologies are natural candidates to become born global firms (Pettersen and Tobiassen 2012). By promoting market orientation, managers will facilitate the development of core capabilities that can increase international competitiveness, such as market sensing and customer linking.

Studies on USOs' success factors have identified, among others, government policies (Liu and Jiang 2001; Budyldina 2018); the characteristics of spin-off processes (Roberts and Malone 1996; Jones-Evans et al. 1998); specific founder qualities (Klofsten and Jones-Evans 2000; Huynh et al. 2017; Hesse and Sternberg 2017); entrepreneurial team formation (Clarysse and Moray 2004); ownership and board composition (Ferretti et al. 2020) and characteristics of technologies, industries and markets (Shane 2001; Nerkar and Shane 2003). The importance of the founder(s) holding an outward-looking attitude, the development of marketing capabilities in the early stage of the new venture's lifecycle and the importance of absorptive capacity to internalize customer knowledge have been widely emphasized (Vohora et al. 2004; Scaringella et al. 2017), but only a few studies have explicitly addressed market orientation (Table 1).

Among others, we recall Roberts' studies (1990 and 1992) on new tech-based firms within the Greater Boston area (spin-offs from MIT laboratories), which described their evolution over the first years after foundation, from consulting and R\&D contracting towards more product (first) and market (last) oriented businesses. In general, Roberts found a generalized lack of market orientation at the time the company was established. For example, numerous companies in the sample, founded by sophisticated technological entrepreneurs, "presumed" market needs based on their own prejudices or feelings rather than on probes of potential customers. In addition, the majority of founders, in the first 6 months of company life, did not reveal awareness of competition (another important component of market orientation): the entrepreneurs frequently claimed they had no competitors, opining that their own products and services were so unique that no other firms' products were relevant.

By collecting data about market orientation during three different periods (founding, year 2 and years 5 to 7), Roberts mapped an evolutionary path towards market 


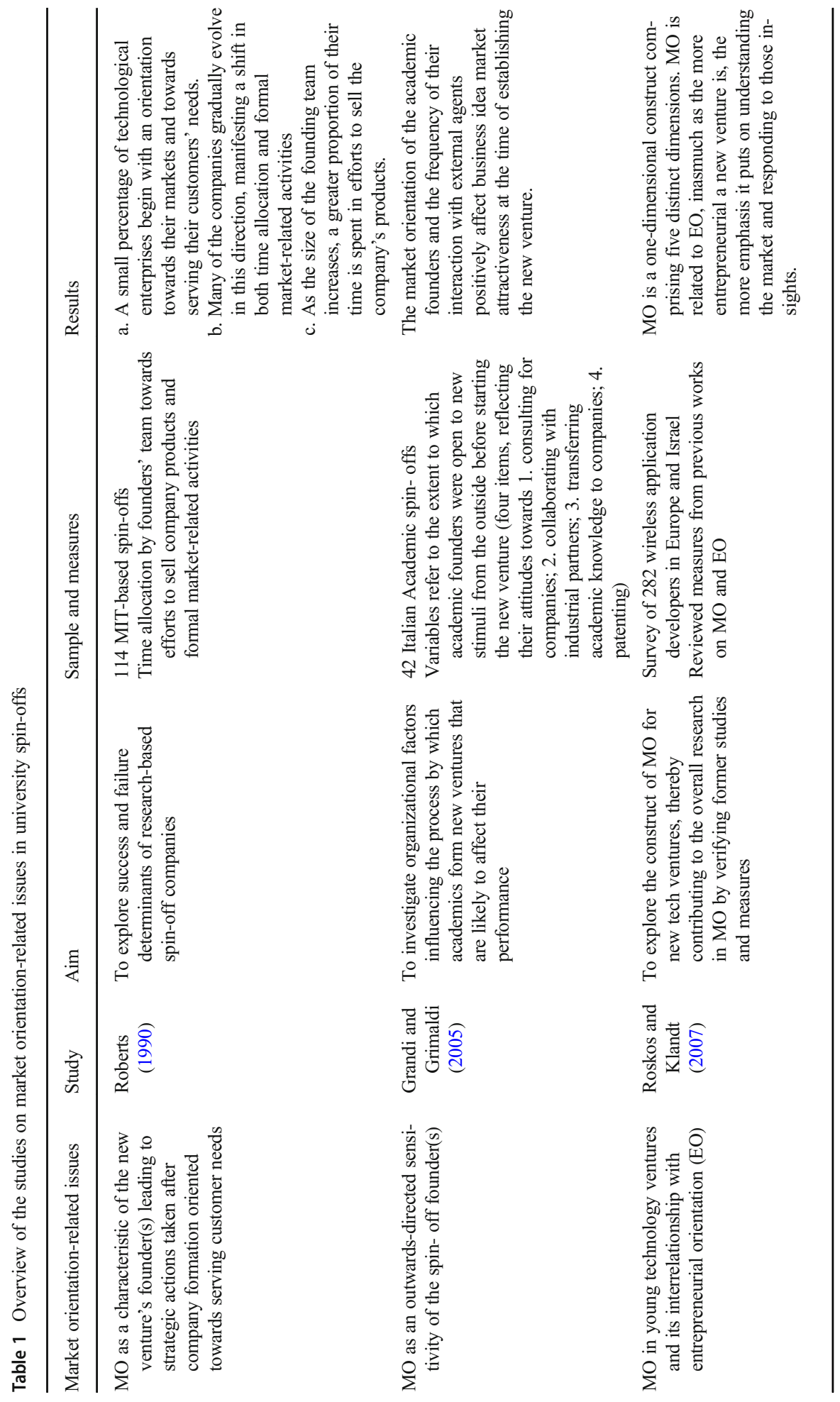




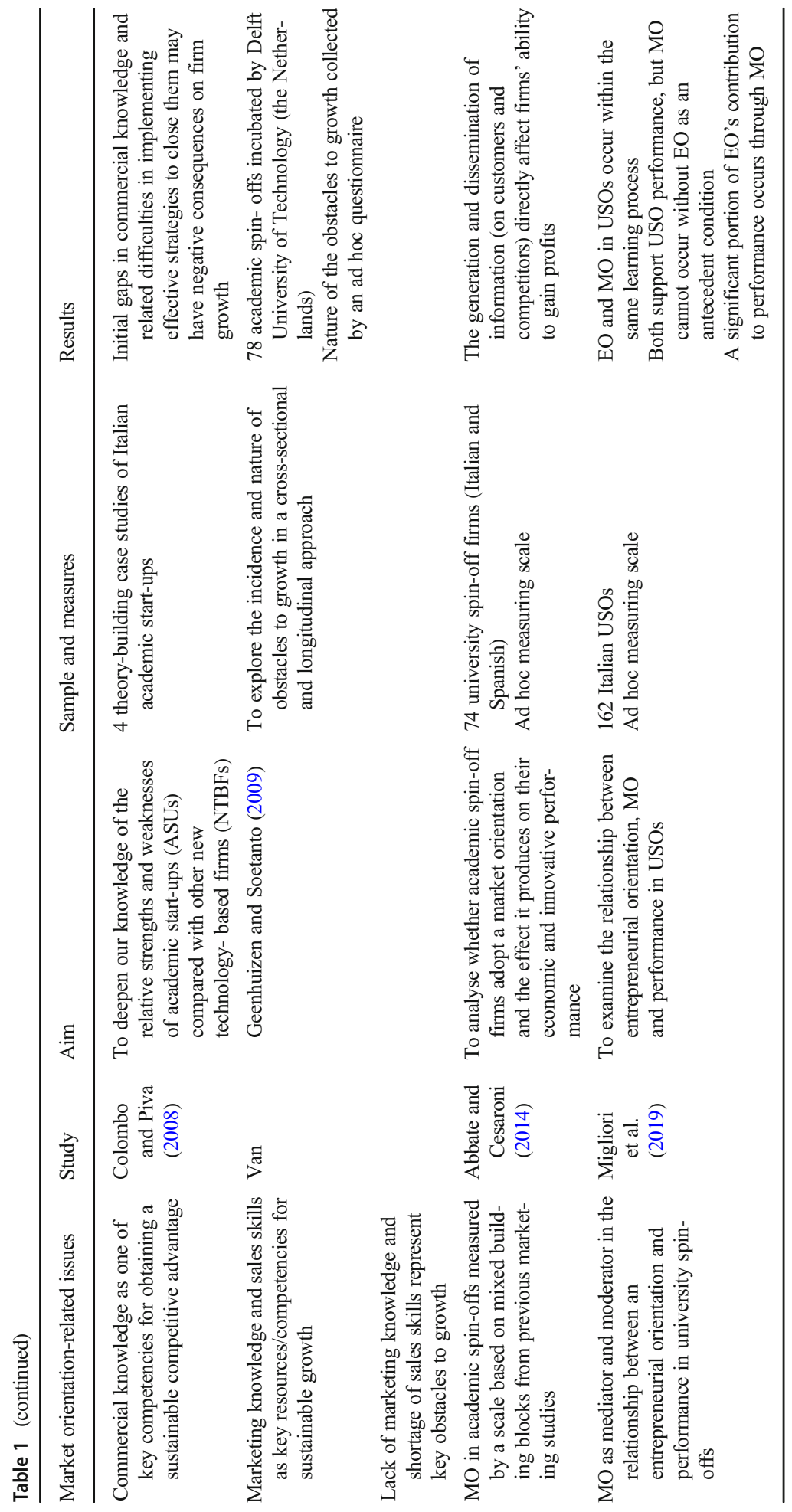


orientation, manifested in several ways. Firms' use of a direct sales force and sales representatives grew over time, as did their adoption of more formal mechanisms such as marketing departments, sales forecasting and analysis of potential markets. Finally, a greater orientation towards marketing in all its dimensions is especially observable in multi-founder firms, where founders may devote a larger part of their time and efforts in activities other than engineering and technical development. The single founder company instead evolves slowly towards developing the cited characteristics.

More specifically examining the relationship between MO and performance in university spin-offs, an empirical study of 125 major MIT laboratories and academic departments showed that 'more successful companies more often use market connected sources, such as customer requests or suggestion for new product ideas, rather than relying on founder ideas alone'...and... '...companies aware of their competition significantly outperformed their less aware cohorts' (Roberts 1992, 10). In sum, establishing a market orientation early in a firm's life bodes well for its future performance, and companies that attain positive results generally tend to establish separate marketing departments as they grow and prosper.

Thus, empirical research confirms that many marketing-related factors are associated with the later success of emerging technology-based companies, beginning with elements present at the time of company formation and later evidenced by organizational developments and practices post-founding. Therefore, Roberts (1992) considers the strategic transformation towards a marketing orientation essential for the longlasting success of the new tech-based company.

Useful insights into the relationship between $\mathrm{MO}$ and performance in university spin-offs also come from an empirical study conducted by Grandi and Grimaldi (2005) on 42 Italian academic spin-off companies. In this study, the authors consider MO as a behavioural attitude of the new venture's founder, i.e. his (her) habits of being open to new stimuli from the outside, transferring knowledge to the marketplace and collaborating and communicating with companies before starting up the new venture.

In particular, they show the importance of the academic founder holding an outwardlooking attitude, so that once acquainted with market requirements, he or she may be able to transfer them into research activities oriented at developing new technologies with higher potential market development, thus defining more attractive business ideas (for investors).

Roskos and Klandt (2007) explored the construct of the MO for new tech ventures using reviewed measures from the work of Kohli et al. (1993) with the aim of pinpointing the interrelationships (if any) with the construct of entrepreneurial orientation (EO). The results defined MO as a one-dimensional construct composed of five distinct dimensions ("intelligence generation on macro environments", "intelligence generation on micro environments", "intelligence generation on customers", "intelligence dissemination" and "responsiveness"). Their research showed that the more entrepreneurial a new tech venture is, the more important it is for the firm to consider its understanding of the market and ability to respond promptly to its dynamics.

In the following years, great attention was given specifically to academic spin-off companies, with the aim of understanding the factors affecting their ability to survive and grow; among others, we review the works conducted by Colombo and Piva (2008) and Van Geenhuizen and Soetanto (2009).

The former study, by focusing on the relative strengths and weaknesses of academic spin-offs compared with other new technology-based firms, showed that their major 
weakness consists of the lack of commercial knowledge. As academic spin-offs suffer from greater initial gaps in this area and encounter serious obstacles in implementing effective strategies to close these gaps, they have a kind of relative disadvantage on the market, which could hinder their ability to grow. From this perspective, commercial knowledge is a mix of information about potential customers and competitors, whereas technical knowledge considers the appropriate way to go to market.

The latter study, by exploring the incidence and nature of obstacles to growth in a crosssectional and longitudinal approach applied to 78 academic spin-offs incubated by Delft University of Technology (the Netherlands), found evidence that market-related obstacles occur most often, with financial and management obstacles in second and third place, respectively. In more detail, a lack of marketing knowledge is the most frequently experienced obstacle, followed by a shortage of sales skills; once again, we found evidence of the importance of adopting an outward-looking approach in managing these firms.

More recently, Abbate and Cesaroni (2014) analysed 74 Italian and Spanish academic spin-offs with the aim of highlighting whether they adopted an MO perspective in running their businesses and the effect it had on their economic and innovation performance. Their study revealed that some components of MO (namely, the generation and dissemination of information about customers and competitors) directly affect firms' ability to develop technological innovations and gain profits; the concept may indeed represent a challenge for spin-off companies and even generate inefficiencies under specific circumstances, particularly when external stimuli require firms to respond quickly.

Finally, Migliori et al. (2019), by examining the relationship between entrepreneurial orientation, market orientation and firms' performance for a cross-sectional sample of 162 Italian USOs, showed that EO and MO occur within the same learning process. Both strategic postures support USO performance, but MO cannot occur without EO as an antecedent condition. At the same time, a significant portion of EO's contribution to performance occurs through MO: the market orientation, in fact, serves a mediating role in the relationship between EO and performance.

To summarize, previous studies on USOs and MO are few and indicate that, in this specific kind of firm, there is a general underestimation of the value of being market oriented when running a business.

However, because university spin-offs operate, by definition, in markets characterized by volatility and uncertainty, we believe that attempting to manage risk by learning the market and responding promptly to market changes to stay ahead of competitors may increase potential rewards. Therefore, higher levels of market orientation should lead university spin-offs to higher performance.

\section{MO and business performance in university spin-offs}

The aforementioned studies related to university spin-offs assessed the MO concept mainly through indirect measures and not based on the conventional scales developed by previous literature on market orientation, such as the MKTOR and MARKOR scales (Narver and Slater 1990; Jaworski and Kohli 1993; Kohli et al. 1993). Such scales, although developed in the 1990s, are still widely diffused among scholars studying the concept of market orientation in small firms, who usually integrate the two scales (Ledwith and O'Dwyer 2009; Raju et al. 2011; Kajalo and Lindblom 2015; Leal-Rodríguez and Albort-Morant 2016). 
To the best of our knowledge, only Roskos and Klandt (2007), Abbate and Cesaroni (2014, 2017) and Migliori et al. (2019) used a scale to examine the MO concept in new tech ventures, academic spin-offs and USOs, respectively, although only the latter two studies analysed the relationship with business performance.

To justify our approach, it may be useful to briefly recall the mainstream results on MO and performance within marketing studies.

The marketing literature has extensively examined the concept of market orientation, highlighting the effect of MO on business performance and generally showing a positive link. Most of the studies focus on large firms, while less attention has been paid to small- and medium-sized enterprises (SMEs) and even less to new high-tech ventures stemming from universities and public research laboratories. Narver and Slater (1990) defined market orientation as an organizational culture leading to organizational behaviours coherent with the creation of superior value for customers. In their conceptualization of market orientation, three components have been considered: (1) customer orientation, (2) competitor orientation and (3) inter-functional coordination.

Customer orientation expresses the firm's ability to understand its target customer, with the aim of creating superior value for that customer. Competitor orientation refers to the generation of information on competitor strategies and its internal dissemination. Inter-functional coordination indicates the alignment of organizational subunits with market-oriented goals, with a strong focus on effective interaction between marketing and R\&D (Narver and Slater 1990; Li and Calantone 1998).

Kohli and Jaworski (1990) instead defined MO by adopting a behavioural approach based on the activities related to its implementation, namely (1) generation of marketing intelligence; (2) dissemination of intelligence across departments and integration into a unified and shared vision of the future and (3) organization-wide responsiveness to intelligence (Kohli and Jaworski 1990; Jaworski and Kohli 1996).

From both perspectives, the operational measures of MO have been developed with the aim of demonstrating the (expected) positive relationship between MO and business profitability, giving birth to a substantial stream of research in the 1990s that explored the antecedents and consequences of market orientation. Generally, the adoption of MO seems to generate higher performance as measured through profitability, sales growth or new product success (Narver and Slater 1990; Ruekert 1992; Deshpandé et al. 1993; Jaworski and Kohli 1993; Slater and Narver 1994b; Atuahene-Gima 1996; Pitt et al. 1996; Deshpandé and Farley 1998; Cano et al. 2004; Liao et al. 2011).

In particular, the relationship between MO and new product success (or, more generally, between MO and firm innovativeness) has been rather controversial: based on empirical studies, some scholars have suggested that being market oriented may lead to $R \& D$ strategies focused on minor improvements in existing technologies/products (Christensen and Bower 1996). The answer to this criticism was the development of a valid measure of MO, which consists of two essential sets of behaviours (Narver et al. 2004). The first is a "responsive" market orientation, in which 'a business attempts to discover, to understand and to satisfy the expressed needs of customers'. The second is a "proactive" market orientation, in which 'a business attempts to discover, to understand and to satisfy the latent needs of customers' (Narver et al. 2004, 335). It is the latter, in particular, that tends to be positively related to innovativeness and, ultimately, to better business performance. 
It is worthwhile to note that the market orientation-innovation-business performance linkage may be moderated by environmental variables, such as technological turbulence (Kohli and Jaworski 1990), level of market uncertainty (Han et al. 1998) and competitive intensity (Jaworski and Kohli 1993; Slater and Narver 1994a).

\section{Research questions}

The above literature review revealed a lack of studies focused on the concept of MO in university spin-offs. In particular, in this specific context, little research exists on the creation and validation of an appropriate scale for measuring MO based on a clear comprehension of the principal dimensions of the MO construct and on the relationship between the different components of $\mathrm{MO}$ and business performance.

The entrepreneurship and business venturing literature, which include USOs, rarely use the MO concept, and when these studies do include it, they treat it as an unusual skill of the founder or as a mix of capabilities critical for survival and growth. Marketing management studies focused on these specific firms are nearly absent.

The present study, therefore, tries to advance the extant literature on this theme by exploring the relationship between MO and business performance in university spinoffs. In particular, assuming an interaction between MO and business performance, our aim is to answer the following research questions:

$\mathrm{RQ}_{1}$ : Which dimensions of $\mathrm{MO}$ are relevant for USOs?

$\mathrm{RQ}_{2}$ : How do the different dimensions of MO affect USO business performance?

\section{Research design}

The empirical research was based on a structured questionnaire conducted on-line, via Google Forms, to a sample of 919 Italian university spin-offs to evaluate their MO from different points of view. The questionnaire, containing a battery of seven-point Likert scales, was built using both the MKTOR and MARKOR scales (Narver and Slater 1990; Jaworski and Kohli 1993; Kohli et al. 1993), following the previous work of Abbate and Cesaroni (2014) that re-elaborated the scale proposed by Mohr et al. (2010) to adapt it to the specificities of academic spin-offs. Such scales have also been extensively used and integrated for measuring MO in smaller firms (Raju et al. 2011; Kajalo and Lindblom 2015; Leal-Rodríguez and Albort-Morant 2016). In particular, five components of market orientation have been identified: customer intelligence generation (both proactive and reactive), competitor intelligence generation, intelligence dissemination, intelligence integration and inter-functional coordination.

A preliminary version of this MO scale was pretested with the founders of three university spin-offs based in Genoa (Italy) to obtain their perceptions and interpretation of the different items; we were interested, in particular, in understanding the applicability of the items to these unique types of new ventures. Based on their comments, we refined some items and approved the first part of the questionnaire containing the final version of the MO scale and comprising 26 items divided into five sections (see Table 2).

Each section of the MO scale measures a particular dimension of the previously identified concept of MO. In particular, we used eight items for measuring customer 
Table 2 Market orientation scale contained in the first part of the questionnaire

\section{Section 1-Customer Intelligence Generation}

Item We continuously work to better understand our customers' needs for new products.

Item We give close attention to after-sales service.

Item We want the customer to think of us allies.

Item We measure customer satisfaction systematically and frequently.

Item We continuously try to discover additional needs of our customers that they might be unaware of. 1.5

Item We incorporate solutions to unconscious customer needs in our new products and services. 1.6

Item We brainstorm about how customer's needs and preferences will evolve.

Item We work with lead users-customers who face needs that eventually will be in the market - but do 1.8 this months or years before the majority of the market.

\section{Section 2-Competitor Intelligence Generation}

Item Employees throughout the organization share information concerning competitor's activities.

Item Top managers regularly discuss competitor's strengths and weaknesses.

Item We rapidly respond to competitive actions that threaten us.

Item We try to anticipate the future moves of our competitors.

Item We monitor firms competing in related products/markets.

Item We monitor firms using related technologies.

Item We monitor firms already targeting our prime market segment but with unrelated products.

\section{Section 3-Intelligence Dissemination}

Item We have interdepartmental meetings to discuss market trends and developments.

Item Marketing personnel spend time discussing customers' needs with other functional departments. 3.2

Item We share information about major market developments.

Item When one function acquires important information about customers or competitors it shares that 3.4 information with other functions.

\section{Section 4-Intelligence Integration}

Item We have cross-functional meetings for the purpose of intelligence integration. 4.1

Item We have cross-functional teams for important initiatives to ensure that all points of view are 4.2 considered before decisions.

Item We value collaboration in this business. 4.3 
Table 2 (continued)

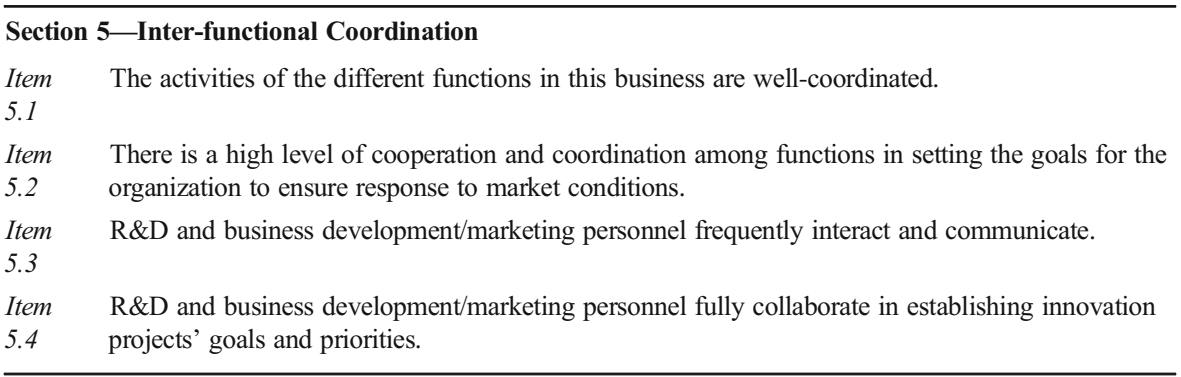

intelligence generation, seven items for competitive intelligence generation, four items for intelligence dissemination, three for intelligence integration and four for interfunctional coordination. The questionnaire items were rated by respondents on a seven-point Likert scale, ranging from one (strongly disagree) to seven (strongly agree).

The second part of the questionnaire asked the respondents to answer three questions related to firm innovativeness, such as, in particular, the number of new products launched on the market in the last 5 years, the number of registered patents and the number of pending patents. Together with this information, we included three questions related to market uncertainty (rate of change in the composition of customers and their preference), competitive intensity and technological turbulence (Kohli and Jaworski 1990; Jaworski and Kohli 1993), as done by Abbate and Cesaroni (2014), to control for environmental uncertainty. The third part included firm-specific information such as industry, firm size (number of employees) and company age (number of years since foundation).

The final version of the questionnaire was published on-line in November 2015 using Google Forms as a website for the on-line survey.

The population for our empirical study consisted of Italian university spin-offs surveyed in the Netval database in 2015 (1330 firms). Based on the existence of the selected firms in the month of November 2015 and the availability of an e-mail address, we selected a list of 919 firms and electronically sent them the questionnaire on November 12, 2015. The survey remained open for 1 month. At the closing date, we collected 115 questionnaires (12.51\% response rate).

To assess the relationship between market orientation and business performance, we integrated the dataset originating from the on-line survey with information on business performance gathered from the AIDA Bureau Van Dijk Database; based on the availability of financial data on the AIDA database, the sample was finally composed of 90 university spin-offs.

\section{Analysis and results}

\section{Sample profiles}

From the geographical point of view, almost all Italian regions are included in our sample (with the exception of Basilicata, Sicilia and Valle d'Aosta). Regarding industry distribution, more than half of the sample belongs to "energy and environment" 
(25.6\%) and "ICT" (26.7\%) industries, while the remaining half belongs to "industrial" $(20.0 \%)$, "life science" (16.7\%) and "social services" (11.0\%).

In general, the university spin-offs in the sample have, on average, 4.26 employees and a longevity of 6.09 years; 61 out of 90 firms present a longevity of at least 3 years.

\section{Validation of MO scale}

To validate the MO scale and understand whether the MO dimensions stemming from the extant literature are also relevant for USOs, we performed an exploratory factor analysis (EFA) on the 26 items included in the first part of the questionnaire (Table 2). Factors were extracted using the principal component method. The total number of factors (four) was defined using the Keiser criterion, which recommends dropping all factors with eigenvalues under one. In this way, we guaranteed a percentage of cumulative explained variance greater than $64 \%$. To measure the appropriateness of the factor analysis, Bartlett's sphericity test $(p$ value $<0.001)$ and the Keiser Meyer Olkin index $(\mathrm{KMO}=0.887)$ were calculated; the results showed that correlations exist in the dataset and are appropriate for factor analysis, as well as that the sampling adequacy is very good.

To simplify the factor structure and make its interpretation more reliable, a Varimax rotation was performed. To check the reliability of the MO scale, we calculated the Cronbach's alpha among items for each extracted factor.

As reported in Table 3, the factors did not load as predicted. In particular, factor 1 (dissemination, integration and inter-functional coordination-DIIC) included three dimensions of MO (i.e. intelligence dissemination, intelligence integration and interfunctional coordination) and 11 items in total. The internal consistency is excellent, as the Cronbach's alpha for this factor is 0.936 .

Factor 2 (competitor intelligence generation-CIGE) loaded as predicted and contained all the items of section 2 of the questionnaire (competitor intelligence generation). The internal consistency is very good (Cronbach's alpha $=0.875$ ).

Section 1 of the questionnaires (customer intelligence generation) was split into two different factors. Factor 3 (proactive customer intelligence generation-PCIG) included all items connected to the proactive customer intelligence generation. Its internal consistency is high (Cronbach's alpha $=0.791$ ). Factor 4 (responsive customer intelligence generation- $\mathrm{RCIG}$ ) included all items connected to responsive customer intelligence generation. Its internal consistency is also high (Cronbach's alpha $=0.723$ ).

To confirm the dimensions of MO obtained from the EFA, a confirmatory factor analysis (CFA) was used to test whether the four-dimensional model suggested by the exploratory factor analysis is an acceptable representation of MO. The CFA results confirmed the four-dimensional structure of MO as suggested by EFA. The goodness of fit of the model is acceptable (RMSEA $=0.044$, CFI $=0.972$, TLI $=0.964$ ).

\section{Testing the impact of MO on business performance}

After factor analysis (EFA and CFA), the extracted MO factors were used to investigate the impact of $\mathrm{MO}$ on business performance. Thus, an OLS regression was performed to test the impact of MO dimensions (DIIC, CIGE, PCIG, RCIG) on the business performance (REVE) of USOs. In relation to the dependent variable, firm business 
Table 3 Results of EFA on the 26 MO scale items

Factor 1. Dissemination, integration and inter-functional coordination (DIIC)

$\begin{array}{rrrrrr}\text { Section 3 } & \text { Item 3.1 } 43.60 & 0.936 & 0.805 & 4.643 & 0.159 \\ & \text { Item 3.2 } & 0.671 & 4.443 & 0.150 \\ & \text { Item } 3.3 & 0.574 & 4.983 & 0.131 \\ \text { Section 4 } & \text { Item } 3.4 & 0.521 & 5.461 & 0.138 \\ & \text { Item } 4.1 & 0.761 & 4.252 & 0.162 \\ \text { Item } 4.2 & 0.703 & 4.904 & 0.166 \\ \text { Section 5 } & \text { Item } 5.1 & 0.731 & 5.435 & 0.138 \\ & \text { Item 5.2 } & 0.743 & 4.939 & 0.140 \\ & \text { Item 5.3 } & 0.776 & 4.974 & 0.136 \\ \text { Item 5.4 } & 0.613 & 5.217 & 0.148 \\ & \text { Item } & 0.584 & 5.165 & 0.145\end{array}$

Factor 2. Competitor intelligence generation (CIGE)

\begin{tabular}{|c|c|c|c|c|c|c|}
\hline \multirow[t]{7}{*}{ Section 2} & Item 2.1 & 9.10 & 0.875 & 0.646 & 4.70 & 0.141 \\
\hline & Item 2.2 & & & 0.811 & 4.478 & 0.140 \\
\hline & Item 2.3 & & & 0.650 & 4.139 & 0.134 \\
\hline & Item 2.4 & & & 0.684 & 4.539 & 0.143 \\
\hline & Item 2.5 & & & 0.809 & 4.974 & 0.142 \\
\hline & Item 2.6 & & & 0.730 & 5.017 & 0.141 \\
\hline & Item 2.7 & & & 0.687 & 4.487 & 0.155 \\
\hline \multicolumn{7}{|c|}{ Proactive customer intelligence generation (PCIG) } \\
\hline \multirow[t]{4}{*}{ Section $1 b$} & Item 1.5 & 7.00 & 0.791 & 0.740 & 5.591 & 0.122 \\
\hline & Item 1.6 & & & 0.674 & 5.426 & 0.129 \\
\hline & Item 1.7 & & & 0.752 & 5.296 & 0.145 \\
\hline & Item 1.8 & & & 0.555 & 5.139 & 0.138 \\
\hline \multicolumn{7}{|c|}{ 4. Responsive customer intelligence generation (RCIG) } \\
\hline \multirow[t]{4}{*}{ Section $1 a$} & Item 1.1 & 4.60 & 0.723 & 0.695 & 5.800 & 0.136 \\
\hline & Item 1.2 & & & 0.772 & 5.417 & 0.139 \\
\hline & Item 1.3 & & & 0.636 & 6.209 & 0.117 \\
\hline & Item 1.4 & & & 0.445 & 4.470 & 0.164 \\
\hline
\end{tabular}

performance, data were obtained from AIDA Bureau Van Dijk Database; it was measured using sales revenues to number of employees, following previous studies (Kirca et al. 2005). As Italian university spin-offs usually present very limited profitability (Iacobucci et al. 2011), we preferred to avoid profitability indexes that could be highly volatile.

Six additional control variables (firm-specific and environmental variables) have been included in the regression analysis, as they have been identified in the extant literature as relevant drivers for USOs' business performance. Some of them are based on firm characteristics, such as industry (INDU) and company longevity (LONG). In 
particular, we included five different industry categories (INDU) that enabled us to cluster spin-off companies based on their technological base and prevailing business: energy and environment, ICT, life science, industrial (B2B innovative product and services) and social services. The other set of variables measures environmental uncertainty: market uncertainty (UNCE), competitive intensity (COMP) and technological turbulence (TURB) (Kohli and Jaworski 1990; Jaworski and Kohli 1993; Kirca et al. 2005). Last, we added a measure of innovation (INNO) based on the number of patents (registered and pending) of the companies. Some differences in firms' business performance may result from these variables, so we controlled for each driver to isolate the unique contribution of the market orientation dimensions. All variables have been operationalized as reported in Table 4.

The results of the regression model, reported in Table 5, show an overall high significance $(\mathrm{F}$-statistic $=5.786, p$ value $<0.001)$ and good explanatory power (adjusted $\left.R^{2}=0.4114\right)$.

\section{Discussion and practical implications}

Regarding the first research question, our study highlights the existence of four MO dimensions relevant for USOs: dissemination, integration and interfunctional coordination (DIIC), competitor intelligence generation (CIGE), proactive customer intelligence generation (PCIG) and responsive customer intelligence generation (RCIG).

In particular, the DIIC dimension combined three previous MO dimensions (i.e. intelligence dissemination, intelligence integration and inter-functional coordination); in effect, university spin-offs could see such dimensions as one, as they usually have, at least in the first years, very simple organizational structures and management functions, with informal methods of communications. Thus, the many dissemination activities and the integration between the different functions of the firm may appear to be less critical among such small companies.

Customer intelligence generation, instead, is split into two different dimensions: PCIG and RCIG. The separation of the two factors is, however, coherent with the results of Narver et al. (2004), which highlighted the bi-dimensional nature of the MO construct. This structure may also derive from the specific features of the business environment, as these firms often operate in very dynamic industries, where the anticipation of customer needs is extremely important and the mere satisfaction of customers' expressed needs may be insufficient to obtain a competitive advantage. Respondents seem aware of the difference between the two and are oriented toward exploring customers' latent needs in a proactive manner.

Regarding the second research question, regression results show that three of the four components, responsive customer intelligence generation (RCIG), proactive customer intelligence generation (PCIG) and dissemination, integration and interfunctional coordination (DIIC), present a significant impact on spin-offs' performance (sales revenues to number of employees).

In particular, RCIG and DIIC positively affect business performance, while PCIG reveals a negative impact. Regarding the positive relationship between DIIC and 


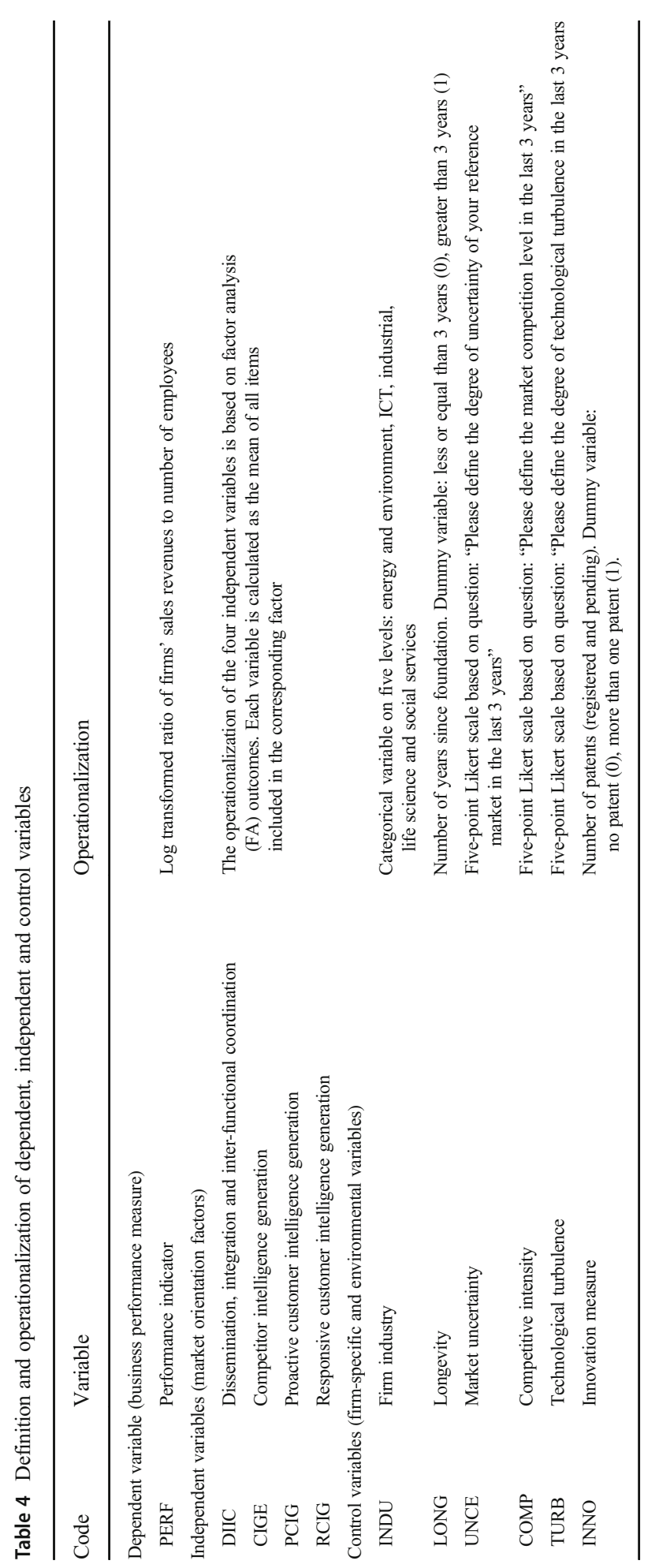


Table 5 Regression analysis results

\begin{tabular}{|c|c|c|c|c|}
\hline & Estimate & SE & $t$ value & \\
\hline Intercept & 3.358 & 0.887 & 3.784 & **** \\
\hline \multicolumn{5}{|l|}{ Independent variables } \\
\hline DIIC & 0.027 & 0.013 & 2.138 & $*$ \\
\hline CIGE & -0.024 & 0.017 & -1.381 & \\
\hline PCIG & -0.125 & 0.037 & -3.397 & $* *$ \\
\hline RCIG & 0.132 & 0.036 & 3.636 & $* * *$ \\
\hline \multicolumn{5}{|l|}{ Control variables } \\
\hline INDU_ICT & -1.36325 & 0.32587 & -4.183 & $* * *$ \\
\hline INDU_Industrial & 0.1184 & 0.37314 & 0.317 & \\
\hline INDU_life science & -0.89746 & 0.3769 & -2.381 & $*$ \\
\hline INDU_Social & -0.74834 & 0.43726 & -1.711 & . \\
\hline LONG & 1.08481 & 0.25292 & 4.289 & $* * *$ \\
\hline UNCE & -0.1514 & 0.13376 & -1.132 & \\
\hline COMP & -0.2999 & 0.12964 & -2.313 & $*$ \\
\hline TURB & 0.14956 & 0.14985 & 0.998 & \\
\hline INNO & -0.44572 & 0.25632 & -1.739 & . \\
\hline$R^{2}$ & & 0.4974 & & \\
\hline Adjusted $R^{2}$ & & 0.4114 & & \\
\hline F-statistic (dof: 13, 76) & & 5.7860 & $* * *$ & \\
\hline
\end{tabular}

$p$ values codes: $. p<0.10 ; * p<0.05 ; * * p<0.01 ; * * * p<0.001$

business performance, our results provide evidence of the importance of creating a business environment where all the activities oriented toward creating customer value are coordinated, and collaboration among the different areas is developed. This research outcome follows the previous literature (Narver and Slater 1990; Kohli and Jaworski 1990; Kara et al. 2005) confirming that, again in firms with low levels of organizational complexity, the focus on knowledge dissemination and integration among different functions may be crucial for attaining good performance.

The result related to customer intelligence generation deserves more attention; while, in fact, the factor (RCIG) confirms previous MO studies (Narver et al. 2004), proactive customer intelligence generation seems to negatively affect business performance, which is contrary to the mainstream literature. In this respect, our study seems to reveal that to be successful, university spin-offs should develop new value propositions able to satisfy the needs of potential customers and not merely apply new technologies to existing products/services. At the same time, their proposition must not anticipate too many customers' expectations because more innovative products are more difficult for both existing customers and the market as a whole (potential customers) to appreciate. Moreover, one could argue that companies that are overly focused on anticipating customers' latent needs require significant investments in R\&D activities that could hinder the attainment of profitable results in the short term. However, this proposition requires further investigation. 
In our study, the acquisition of information relating to competitors' strategic moves, competitor intelligence generation (CIGE), presents a non-significant effect on business performance, with a negative trend. This result may sound quite unconventional, but it seems to be coherent with some previous studies on the topic.

Gatignon and Xuereb (1997), finding similar results in their research on the relationship between $\mathrm{MO}$ and innovation performance in different types of industry, suggest: '...a competitive orientation is recommended ...when demand is not too uncertain and in growing markets but should be de-emphasized in highly uncertain markets...' Similarly, Van Riel et al. (2004), in their study on high-tech services, found that the acquisition of competitive information has a significant negative effect on the likelihood of short-term innovation success. Even if attempts to imitate competitors' successful value propositions are very common, particularly in high-tech services, past research demonstrates that products/services that are not unique and not evidently superior to competitive offerings are prone to failures (Dutta et al. 1999). Moreover, one could also argue that firms overly focused on generating intelligence on competitors may overlook customers' requirements, thereby losing opportunities to satisfy their actual expectations. Finally, underestimating the need to generate competitor intelligence may be connected on university spin-off strategic behaviour: the adoption of niche positioning strategies may protect them, at least temporarily, from direct competition. After all, this strategic behaviour has been highly documented (Roure and Maidique 1986; Roure and Keeley 1990; Arora et al. 2001). New companies in high-tech markets may indeed try to control their destinies by positioning themselves in market niches with low levels of competition, markets in which they anticipate a major role in shaping standards and customer expectations. In sum, we may conclude on this matter that the recommendations for which strategic orientation to emphasize are not unconditional.

The results of this study demonstrate that MO has an impact on the business performance of USOs. More precisely, the analysis conducted indicates that the dimensions of customer intelligence generation and intelligence dissemination, integration and inter-functional coordination influenced the MO of USOs, which, in turn, impacts firm performance as measured by operating variables (sales revenues to number of employees). Therefore, these factors may be considered critical to the success of USOs; their presence in this kind of firm may indicate that entrepreneurs (or the entrepreneurial team) should give attention to the evaluation of customers' needs and expectations and to the assessment of their satisfaction with the product/service delivery system. Seemingly, the analysis suggests that entrepreneurs value the dissemination of information among their staff and that this practice may lead to superior performance through the ability to respond to market change faster than competitors do.

Taking up the second research question, we may conclude that although the relationship between university spin-offs' $\mathrm{MO}$ and performance may be more complex than that analysed in this study, our research provides some empirical evidence suggesting that better performance may be achieved by USOs adopting a "market orientation" in running their business. This finding is noteworthy, taking into account that new firms stemming from research and technological development are very often born global, as their market is at least potentially at a global scale. From this perspective, being market oriented may be a key strategic posture for success because it may reduce the risk of strategic choices characterized by intrinsic uncertainty. 


\section{Conclusions}

In this study, we tried to extend previous literature on university spin-offs with two principal aims: understanding the MO dimensions relevant for USOs, through the development of a valid measuring scale of the MO construct for these specific companies and examining the relationship between $\mathrm{MO}$ and business performance. The results show that the MO construct in USOs can be split into four dimensions, but not all dimensions present the same effect on business performance. In particular, responsive customer intelligence generation (RCIG) and dissemination, integration and inter-functional coordination (DIIC) seem to positively affect business performance; proactive customer intelligence generation (PCIG) reveals a negative impact, while competitor intelligence generation (CIGE) presents a non-significant effect on business performance, with a negative trend.

Our study has some limitations, which provide possible starting points for future research. First, our analysis takes into account only one financial year, 2015; future studies should instead consider conducting a longitudinal analysis for a deeper understanding of the relationship between MO and business performance (as in Noble et al. 2002).

The second limitation stems from the measurement of firms' business performance. Sales revenues to number of employees is indeed a better measure than profitability indexes, as university spin-offs usually present very limited profitability, and such indexes can be highly volatile, but in the future, new measures of business performance should be used that are not necessarily linked to financial results. Such results are, in fact, very difficult to reach in the first years following the firm's founding: perhaps the capacity for attracting capital investment from business angels, venture capitalists or private equity funds could constitute a valid alternative measure of business performance in such type of firms.

Finally, our sample is generated by a voluntary self-reporting process that might lead to the inclusion in the analysis of companies that are already biased towards a market orientation and who thus wish to report it.

Despite such limitations, we can draw from this study some insights into the nature and consequences of MO in USOs.

Within the market orientation literature, our study confirms the importance of examining the construct in a disaggregated manner: we are conscious that the components of MO are conceptually linked and should be considered as a whole, but a disaggregated approach enables us to pinpoint the relative value of each component. This is particularly important when analysing a specific kind of firm, such as USO, that shows some unique features from both an organizational and a strategic perspective. Regarding instead the relationship between MO components and USO business performance, our study confirms the importance of both customer intelligence generation and inter-functional coordination, while at the same time showing an unexpected result regarding proactive customer intelligence generation. We may speculate that the risk of over-aggressively anticipating customers' expectations by developing radical innovations is one of the biggest failures for USOs. At the same time, the lack of significance for the competitor orientation dimension is provocative and worthy of further research, but it is coherent with some previous studies on the topic. 
Our analysis also adds some reflections within the academic entrepreneurship literature, highlighting the relevance of being market oriented to attain better results when exploiting research results for commercial purposes. Studies on this topic have reported either the hybrid nature of entrepreneurial posture in USOs or the lack of market knowledge and commercial resources as the main motivations for poor performance and slow growth. Our results show more precisely that the ability to identify market opportunities stemming from new technological applications through the satisfaction of actual or latent needs is of paramount importance for survival and growth.

In conclusion, we believe that these findings may be useful for researchers and academics engaged in entrepreneurial initiatives, as the approach adopted in our study lends itself to more precise insights for those who are interested in developing marketoriented organizations aiming at better performance.

Furthermore, we think that our results may also be useful for professionals from new high-tech venture and technology transfer offices, who may use these results to plan and design market-focused actions and support activities that will lead to the improved business performance of USOs.

Acknowledgments The authors want to express their gratitude to Editor-in-Chief Professor Hamid Etemad and to the two anonymous reviewers for comments and suggestions that much helped improving this manuscript.

Authors' contribution Authors equally contributed to this paper.

Funding Information Open access funding provided by Università degli Studi di Genova within the CRUICARE Agreement.

Open Access This article is licensed under a Creative Commons Attribution 4.0 International License, which permits use, sharing, adaptation, distribution and reproduction in any medium or format, as long as you give appropriate credit to the original author(s) and the source, provide a link to the Creative Commons licence, and indicate if changes were made. The images or other third party material in this article are included in the article's Creative Commons licence, unless indicated otherwise in a credit line to the material. If material is not included in the article's Creative Commons licence and your intended use is not permitted by statutory regulation or exceeds the permitted use, you will need to obtain permission directly from the copyright holder. To view a copy of this licence, visit http://creativecommons.org/licenses/by/4.0/.

\section{References}

Abbate T, Cesaroni F (2014) Market orientation and academic spin-off firms. INDEM - Working Paper Business Economic Series, WP 14-01:1-26

Abbate T, Cesaroni F (2017) The (needed?) market orientation of academic spin-off firms. International Journal of Entrepreneurship and Innovation Management 21:395

Appiah-Adu K (1998) Market orientation and performance: do the findings established in large firms hold in the small business sector? Journal of Euromarketing 6(3):1-26. https://doi.org/10.1300/J037v06n03_01

Armario JM, Ruiz DM, Armario EM (2008) Market orientation and internationalization in small and mediumsized enterprises. J Small Bus Manag 46(4):485-511. https://doi.org/10.1111/j.1540-627X.2008.00253.x

Arora A, Gambardella A, Torrisi S (2001) In the footsteps of Silicon Valley? Indian and Irish software in the international division of labour. SIEPR Discussion Paper No. 00-41

Atuahene-Gima K (1996) Market orientation and innovation. J Bus Res 35(2):93-103. https://doi.org/10.1016 /0148-2963(95)00051-8 
Budyldina N (2018) Entrepreneurial universities and regional contribution. Int Entrep Manag J 14(2):265277. https://doi.org/10.1007/s11365-018-0500-0

Buratti N, Ferrando PM, Siria S. (2014a) Assessing the performance of RBSOs. Survival through slow growth patterns. ICSB World Conference Proceedings: $1-4$

Buratti N, Ferrando PM, Siria S (2014b) Spin-off della ricerca come strumento di sviluppo locale? Primi risultati di una ricerca empirica sugli spin-off in Liguria. Sinergie quaderni di ricerca 17:175-194

Buratti N, Ferrando PM, Siria S (2015) Percorsi di sviluppo e performance delle imprese spin-off della ricerca: risultati di una analisi longitudinale sugli spin-off dell'Università di Genova. Economia e Diritto del Terziario 3:373-400

Cano CR, Carrillat FA, Jaramillo F (2004) A meta-analysis of the relationship between market orientation and business performance: evidence from five continents. Int J Res Mark 21(2):179-200. https://doi. org/10.1016/j.ijresmar.2003.07.001

Chang TZ, Chen SJ (1998) Market orientation, service quality and business profitability: a conceptual model and empirical evidence. J Serv Mark 12(4):246-264. https://doi.org/10.1108/08876049810226937

Christensen CM, Bower JL (1996) Customer power, strategic investment, and the failure of leading firms. Strat Manag J 17(3):197-218. https://oi.org/10.1002/(SICI)1097-0266(199603)17:3\%3C197::AIDSMJ804\%3E3.0.CO;2-U

Clarysse B, Moray N (2004) A process study of entrepreneurial team formation: the case of a research-based spin-off. J Bus Ventur 19(1):55-79. https://doi.org/10.1016/S0883-9026(02)00113-1

Colombo MG, Piva E (2008) Strengths and weaknesses of academic startups: a conceptual model. IEEE Trans Eng Manag 55(1):37-49. https://doi.org/10.1109/TEM.2007.912807

Covin JG, Covin TJ (1990) Competitive aggressiveness, environmental context, and small firm performance. Enterp Theory Pract 14(4):35-50. https://doi.org/10.1177/104225879001400406

De Luca LM, Verona G, Vicari S (2010) Market orientation and R\&D effectiveness in high-technology firms: an empirical investigation in the biotechnology industry. J Prod Innov Manag 27(3):299-320. https://doi. org/10.1111/j.1540-5885.2010.00718.x

Deshpandé R (ed) (1999) Developing a market orientation. Sage Publications, Thousand Oaks

Deshpandé R, Farley JU (1998) Measuring market orientation: generalization and synthesis. J Market-Focused Manage 2(3):213-232. https://doi.org/10.1023/A:1009719615327

Deshpandé R, Farley JU, Webster FE Jr (1993) Corporate culture, customer orientation, and innovativeness in Japanese firms: a quadrad analysis. J Mark 57(1):23-37. https://doi.org/10.1177/002224299305700102

Di Gregorio D, Shane S (2003) Why do some universities generate more start-ups than others? Res Policy 32(2):209-227. https://doi.org/10.1016/S0048-7333(02)00097-5

Dutta S, Narasimhan O, Rajiv S (1999) Success in high-technology markets: is marketing capability critical? Mark Sci 18(4):547-568. https://doi.org/10.1287/mksc.18.4.547

Ferretti M, Ferri S, Fiorentino R, Parmentola A, Sapio A (2020) What drives the growth of academic spinoffs? Matching academics, universities, and non-research organizations. Int Entrep Manag J 16:137-163. https://oi.org/10.1007/s11365-018-0497-4

Fitza M, Matusik SF, Mosakowski E (2009) Do VCs matter? The importance of owners on performance variance in start-up firms. Strateg Manag J 30(4):387-404. https://doi.org/10.1002/smj.748

Gatignon H, Xuereb JM (1997) Strategic orientation of the firm and new product performance. JMark Res 34(1):77-90. https://doi.org/10.1177/002224379703400107

Grandi A, Grimaldi R (2005) Academics' organizational characteristics and the generation of successful business ideas. J1 Bus Ventur 20(6):821-845. https://doi.org/10.1016/j.jbusvent.2004.07.002

Han JK, Kim N, Srivastava RK (1998) Market orientation and organizational performance: is innovation a missing link? J Mark 62(4):30-45. https://doi.org/10.1177/002224299806200403

Heirman A, Clarysse B (2004) How and why do research-based start-ups differ at founding? A resource-based configurational perspective. J Technol Transf 29(3-4):247-268. https://doi.org/10.1023 /B:JOTT.0000034122.88495.0d

Helm R, Mauroner O, Dowling M (2010) Innovation as mediator between entrepreneurial orientation and spin-off venture performance. Int J Entrep Small Bus 11(4):472-491. https://doi.org/10.1504 /IJESB.2010.036298

Hesse N, Sternberg R (2017) Alternative growth patterns of university spin-offs: why so many remain small? Int Entrep Manag J 13(3):953-984. https://doi.org/10.1007/s11365-016-0431-6

Huynh T, Patton D, Arias-Aranda D, Molina-Fernández LM (2017) University spin-off's performance: capabilities and networks of founding teams at creation phase. J Bus Res 78:10-22. https://doi. org/10.1016/j.jbusres.2017.04.015

Iacobucci D, Iacopini A, Micozzi A, Orsini S (2011) Fostering entrepreneurship in academic spin-offs. Int J Entrep Small Bus 12(4):513-533. https://doi.org/10.1504/IJESB.2011.039689 
Jaworski BJ, Kohli AK (1993) Market orientation: antecedents and consequences. J Mark 57(3):53-70. https://doi.org/10.1177/002224299305700304

Jaworski BJ, Kohli AK (1996) Market orientation: review, refinement, and roadmap. J Market-Focused Manage 1(2):119-135. https://doi.org/10.1007/BF00128686

Jones-Evans DFS, Balazs K, Todorov K (1998) Public sector entrepreneurship in central and eastern Europe: a study of academic spin-offs in Bulgaria and Hungary. J Appl Manag Stud 7(1):59-76

Kajalo S, Lindblom A (2015) Marketorientation, entrepreneurial orientation and business performance among small retailers. Int J Retail Distrib Manag 43(7):580-596. https://doi.org/10.1108/IJRDM-04-2014-0044

Kara A, Spillan JE, DeShields OW (2005) The effect of a market orientation on business performance: a study of small-sized service retailers using MARKOR scale. J Small Bus Manag 43(2):105-118

Keskin H (2006) Market orientation, learning orientation, and innovation capabilities in SMEs: an extended model. Eur J Innov Manag 9(4):396-417. https://doi.org/10.1108/14601060610707849

Kirca AH, Jayachandran S, Bearden WO (2005) Market orientation: a meta-analytic review and assessment of its antecedents and impact on performance. J Mark 69(2):24-41. https://doi.org/10.1509 /jmkg.69.2.24.60761

Klofsten M, Jones-Evans D (2000) Comparing academic entrepreneurship in Europe-the case of Sweden and Ireland. Small Bus Econ 14(4):299-309. https://doi.org/10.1023/A:1008184601282

Kohli AK, Jaworski BJ (1990) Market orientation: the construct, research propositions, and managerial implications. J Mark 54(2):1-18. https://doi.org/10.1177/002224299005400201

Kohli AK, Jaworski BJ, Kumar A (1993) MARKOR: a measure of market orientation. J Mark Res 30(4):467477. https://doi.org/10.1177/002224379303000406

Leal-Rodríguez AL, Albort-Morant G (2016) Linking market orientation, innovation and performance: an empirical study on small industrial enterprises in Spain. J Small Bus Strategy 26(1):37-50

Ledwith A, O'Dwyer M (2009) Market orientation, NPD performance, and organizational performance in small firms. J Prod Innov Manag 26(6):652-661. https://doi.org/10.1111/j.1540-5885.2009.00690.x

Lerner J (2004) The university and the start-up: lessons from the past two decades. J Technol Transf 30(1-2): 49-56. https://doi.org/10.1007/s10961-004-4357-8

Li T, Calantone RJ (1998) The impact of market knowledge competence on new product advantage: conceptualization and empirical examination. J Mark 62(4):13-29. https://doi.org/10.1177 /002224299806200402

Liao SH, Chang WJ, Wu CC, Katrichis JM (2011) A survey of market orientation research (1995-2008). Ind Mark Manag 40(2):301-310. https://doi.org/10.1016/j.indmarman.2010.09.003

Liu H, Jiang Y (2001) Technology transfer from higher education institutions to industry in China: nature and implication. Technovation 21(3):175-188. https://doi.org/10.1016/S0166-4972(00)00045-6

Lockett A, Siegel D, Wright M, Ensley MD (2005) The creation of spin-off firms at public research institutions: Managerial and policy implications. Research Policy 34:981-993

Lumpkin GT, Dess GG (1996) Clarifying the entrepreneurial orientation construct and linking it to performance. Acad Manag Rev 21(1):135-172. https://doi.org/10.5465/amr.1996.9602161568

Matsuno K, Mentzer JT (2000) The effects of strategy type on the market orientation-performance relationship. J Mark 64(4):1-16. https://doi.org/10.1509/jmkg.64.4.1.18078

Migliori S, Pittino D, Consorti A, Lucianetti L (2019) The relationship between entrepreneurial orientation, market orientation and performance in university spin-offs. Int Entrep Manag J:793-814. https://doi. org/10.1007/s11365-017-0488-x

Miller D (1983) The correlates of entrepreneurship in three types of firms. Manag Sci 29(7):770-791. https://doi.org/10.1287/mnsc.29.7.770

Mohr J, Sengupta S, Slater S (2010) Marketing of high-technology products and innovations, 3rd edn. Pearson Education, Upper Saddle River

Mustar P, Wright M, Clarysse B (2008) University spin-off firms: lessons from ten years of experience in Europe. Sci Public Policy 35(2):67-80. https://doi.org/10.3152/030234208X282862

Narver JC, Slater SF (1990) The effect of a market orientation on business profitability. J Mark 54(4):20-35

Narver JC, Slater SF, MacLachlan DL (2004) Responsive and proactive market orientation and new-product success. J Prod Innov Manag 21(5):334-347. https://doi.org/10.1111/j.0737-6782.2004.00086.x

Nerkar A, Shane S (2003) When do start-ups that exploit patented academic knowledge survive? Int J Ind Organ 21(9):1391-1410. https://doi.org/10.1016/S0167-7187(03)00088-2

Nicolaou N, Birley S (2003) Academic networks in a trichotomous categorisation of university spinouts. J Bus Ventur 18(3):333-359. https://doi.org/10.1016/S0883-9026(02)00118-0

Noble CH, Sinha RK, Kumar A (2002) Market orientation and alternative strategic orientations: a longitudinal assessment of performance implications. J Mark 66(4):25-39. https://doi.org/10.1509 /jmkg.66.4.25.18513 
O'Shea RP, Allen TJ, Chevalier A, Roche F (2005) Entrepreneurial orientation, technology transfer and spinoff performance of US universities. Res Policy 34(7):994-1009. https://doi.org/10.1016/j. respol.2005.05.011

Pelham AM (2000) Market orientation and other potential influences on performance in small and mediumsized manufacturing firms. J Small Bus Manag 38(1):48-67

Perez MP, Sánchez AM (2003) The development of university spin-offs: early dynamics of technology transfer and networking. Technovation 23(10):823-831. https://doi.org/10.1016/S0166-4972(02)00034-2

Pettersen IB, Tobiassen AE (2012) Are born globals really born globals? The case of academic spin-offs with long development periods. J Int Entrep 10(2):117-141. https://doi.org/10.1007/s10843-012-0086-5

Pitt L, Caruana A, Berthon PR (1996) Market orientation and business performance: some European evidence. Int Mark Rev 13(1):5-18. https://doi.org/10.1108/02651339610111317

Polo Peña AI, Frías Jamilena DM, Rodríguez Molina MÁ (2011) Impact of market orientation and ICT on the performance of rural smaller service enterprises. J Small Bus Manag 49(3):331-360. https://doi. org/10.1111/j.1540-627X.2011.00332.x

Raju PS, Lonial SC, Gupta YP, Ziegler C (2000) The relationship between market orientation and performance in the hospital industry: a structural equations modeling approach. Health Care Manag Sci 3(3): 237-247. https://doi.org/10.1023/A:1019061912075

Raju PS, Lonial SC, Crum MD (2011) Market orientation in the context of SMEs: a conceptual framework. J Bus Res 64(12):1320-1326. https://doi.org/10.1016/j.jbusres.2010.12.002

Rasmussen E, Mosey S, Wright M (2011) The evolution of entrepreneurial competencies: a longitudinal study of university spin-off venture emergence. J Manag Stud 48(6):1314-1345. https://doi.org/10.1111/j.14676486.2010.00995.x

Roberts EB (1990) Evolving toward product and market-orientation: the early years of technology-based firms. J Prod Innov Manag 7(4):274-287. https://doi.org/10.1016/0737-6782(90)90075-P

Roberts EB (1992) The success of high-technology firms: early technological and marketing influences. Interfaces 22(4):3-12. https://doi.org/10.1287/inte.22.4.3

Roberts EB, Malone DE (1996) Policies and structures for spinning off new companies from research and development organizations. R\&D Manag 26(1):17-48. https://doi.org/10.1111/j.1467-9310.1996. tb00927.x

Roskos S, Klandt H (2007) Young technology ventures in Europe: aspects of market orientation and entrepreneurial orientation. Int J Entrep Small Bus 4(5):543-563. https://doi.org/10.1504 /IJESB.2007.014389

Roure JB, Keeley RH (1990) Predictors of success in new technology based ventures. J Bus Ventur 5(4):201220. https://doi.org/10.1016/0883-9026(90)90017-N

Roure JB, Maidique MA (1986) Linking prefunding factors and high-technology venture success: an exploratory study. J Bus Ventur 1(3):295-306. https://doi.org/10.1016/0883-9026(86)90006-6

Ruekert RW (1992) Developing a market orientation: an organizational strategy perspective. Int J Res Mark 9(3):225-245. https://doi.org/10.1016/0167-8116(92)90019-H

Scaringella L, Miles RE, Truong Y (2017) Customers' involvement and firm absorptive capacity in radical innovation: the case of technological spin-offs. Technol Forecast Soc Change 120:144-162. https://doi. org/10.1016/j.techfore.2017.01.005

Shane S (2001) Technological opportunities and new firm creation. Manag Sci 47(2):205-220. https://doi. org/10.1287/mnsc.47.2.205.9837

Shane S, Stuart T (2002) Organizational endowments and the performances of university start-ups. Manag Sci 48(1):154-170. https://doi.org/10.1287/mnsc.48.1.154.14280

Slater SF, Narver JC (1994a) Does competitive environment moderate the market orientation-performance relationship? J Mark 58(1):46-55. https://doi.org/10.1177/002224299405800104

Slater SF, Narver JC (1994b) Market orientation, customer value, and superior performance. Bus Horiz 37(2): $22-28$

Van Geenhuizen M, Soetanto DP (2009) Academic spin-offs at different ages: a case study in search of key obstacles to growth. Technovation 29(10):671-681. https://doi.org/10.1016/j.technovation.2009.05.009

Van Riel AC, Lemmink J, Ouwersloot H (2004) High-technology service innovation success: a decisionmaking perspective. J Prod Innov Manag 21(5):348-359. https://doi.org/10.1111/j.07376782.2004.00087.x

Verhees FJ, Meulenberg MT (2004) Market orientation, innovativeness, product innovation, and performance in small firms. J Small Bus Manag 42(2):134-154. https://doi.org/10.1111/j.1540-627X.2004.00102.x

Vohora A, Wright M, Lockett A (2004) Critical junctures in the development of university high-tech spinout companies. Res Policy 33(1):147-175. https://doi.org/10.1016/S0048-7333(03)00107-0 
Walsh ST, Kirchhoff BA, Newbert S (2002) Differentiating market strategies for disruptive technologies. IEEE Transactions on Engineering Management 49:341-351

Walsh ST, Linton JD (2011) The Strategy-Technology Firm Fit Audit: A guide to opportunity assessment and selection. Technological Forecasting and Social Change 78:199-216

Walter A, Auer M, Ritter T (2006) The impact of network capabilities and entrepreneurial orientation on university spin-off performance. J Bus Ventur 21(4):541-567. https://doi.org/10.1016/j. jbusvent.2005.02.005

Wu LY (2007) Entrepreneurial resources, dynamic capabilities and start-up performance of Taiwan's high-tech firms. J Bus Res 60(5):549-555. https://doi.org/10.1016/j.jbusres.2007.01.007

Würmseher M (2017) To each his own: matching different entrepreneurial models to the academic scientist's individual needs. Technovation 59:1-17. https://doi.org/10.1016/j.technovation.2016.10.002

Yagüe-Perales RM, March-Chordà I (2012) Performance analysis of research spin-offs in the Spanish biotechnology industry. J Bus Res 65(12):1782-1789. https://doi.org/10.1016/j.jbusres.2011.10.038

Publisher's note Springer Nature remains neutral with regard to jurisdictional claims in published maps and institutional affiliations. 